\title{
The Research of the Distinguishing Features of Blue and Leisure Sports in Liveable Cities -----Taking Weihai as an Example
}

\author{
Zhang Qi \\ Shandong University (Weihai), Department of Physical Education, Weihai, Shandong, China (57065025@qq.com)
}

\begin{abstract}
This paper is to study the current state of blue and leisure sports at Weihai by using the methods of documentation, statistics and questionnaire. This paper mainly introduces the forms of highly-participated blue leisure sports at Weihai such as sailing boats, golf, swimming and badminton, etc. And it also analyzes the distinguishing features of it, including the characteristics of the co-existance of tradition and modernity, the indication of popularity and stratum, and the prominence of seasonality and tourism.
\end{abstract}

Key words — weihai, blue, leisure sports, distinguishing features

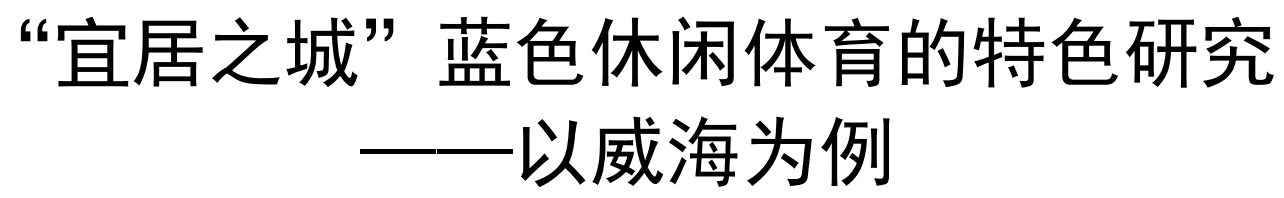

张奇

山东大学（威海）体育教学部, 威海, 山东, 中国

\begin{abstract}
摘 要 本文运用文献资料、统计、问卷等方法对威海地区的蓝色休闲体育现状进行研究, 主要介绍了威海帆船、高尔夫、游泳、 羽毛球、健身路径参与度较高的蓝色休闲体育形式, 并分析梳理了威海蓝色休闲体育的特色, 包括传统性与现代性并存, 全民性与阶 层性共显, 季节性与旅游性突出的特点。
\end{abstract}

关键词 威海, 蓝色, 休闲体育, 特色

休闲体育是社会体育的组成部分, 是人们在闲暇 (工 作、学习、劳动、家务、社会义务之外的）时间主动进行 的, 以增进身心健康、丰富和创造生活情趣、完善自我为 目的的身体锻炼活动。人们在可以自由支配的余暇时间里 进行锻炼, 以寻求身心放松、获得愉快情感体验、提高生 活质量, 且这种 “活动”一般不计任何报酬, 具有非功利 性。它追求运动本身所带来的个体独享的或群体共享的乐 趣。

随着生产力水平的提高, 人们消费结构更加多元, 充 足的资金和可自由支配的闲暇时光使得休闲体育发展十分 迅速。在我国, 休闲体育已成为全国性的、全民性的、普 遍性的运动方式, 具有自由性、文化性、非功利性和主动 性等特点。不同地域有着不同的文化底蕴和生活习惯, 文 化与习惯上的差异性使得休闲体育有着地域性的特色, 本
文就威海地区的蓝色休闲体育为研究对象, 分析威海蓝色 休闲体育的主要项目与其特色。

\section{1. 威海蓝色休闲体育的主要项目}

威海位于胶东半岛最东端, 北东南三面毗邻黄海, 北 与辽东半岛相对, 东及东南与朝鲜半岛和日本列岛隔海相 望, 西与烟台市接壤。威海市是全国投资硬环境 40 优城市, 也是全国综合经济实力 50 强城市, 1984 年成为第一批中 国沿海开放城市, 1990 年被评为中国第一个国家卫生城市, 1996 年被建设部命名为国家园林城市, 1997 年 10 月 13 日 被国家环保部授予国家环境保护模范城市, 1999 年 1 月成 为第一批中国优秀旅游城市, 2003 年 10 月 6 日获得联合 国人居奖的中国城市, 2009 年 5 月 7 日被评选为国家森林 城市。 
威海有着得天独厚的自然环境条件。威海市地处中纬 度, 属于北温带季风型大陆性气候, 但受海洋的调节作用, 又具有春冷、夏凉、秋暖、冬温, 昼夜温差小、无霜期长、 大风多和湿度大等海洋性气候特点。全市历年平均气温 $11.9^{\circ} \mathrm{C}$, 历年平均降水量 730.2 毫米, 历年平均日照时数 2538.2 小时。威海有 1000 公里的海岸线, 占山东省 $1 / 3$, 全国的 $1 / 18$, 海岸类型属于港湾海岸, 海岸线曲折, 沿海 有大小港湾 30 多处, 岬角 20 多个, 并有众多优质海滩分 布。全市大小海岛 168 个, 其中, 面积 500 平方米以上的 98 个, 有居民岛屿 6 个。

蓝天、碧海、沙滩是威海的天然条件。威海的休闲体 育运动项目也与海水、海风、海浪、海岸、阳光、沙滩、 绿色植被等自然条件紧紧相依, 有着内陆地区无法比拟的 优越自然环境和活动条件。威海的蓝色休闲体育主要包括 帆船、游泳、沙滩排球、沙滩足球、骑行、健步走、羽毛 球等等一系列的体育项目。其中, 帆船、高尔夫、羽毛球、 全民健身路径、游泳是威海极具特色或参与人数较多的几 个休闲体育项目。

\section{1 帆船}

威海市发展帆船运动有 5 个特点: 优势、规划、投入、 赛事、成效。威海无论是海岸线的长度还是风浪条件都是 有着得天独厚的优势的。威海政府也相当重视帆船活动, 将帆船活动列入威海市 “十二五”规划, 并且安排相应的财 政资金, 对帆船场地场馆建设进行投入。威海市政府还每 年从政府财政中拿出一定的资金培养 OP 船员, 最小的船 员从小学就开始挑选和培养。随着威海对帆船运动的愈发 重视, 近几年威海围绕帆船活动举办了许多大型国际帆船 赛事, 例如 2009 年举办威海杯中国首届国际帆船锦标赛 等, 并和青岛、韩国仁川合作举行了多项赛事。帆船和帆 船产业在威海引起了强烈的反响, 威海的游艇、帆船产业 也得到了长足的发展, 很多市民和爱好者逐渐地参与到帆 船运动的体验活动中来。

\section{2 高尔夫}

高尔夫球是一种以棒击球入穴的球类运动, 是一种在 优美环境中进行的高尚娱乐活动。“高尔夫一词是荷兰文 kolf 的音译, 意思是"在绿地和新鲜氧气中的美好生活"。由 于进行这种游戏所需的设备昂贵, 对场地的要求也很高, 所以在一些国家又叫它 “贵族球”。如今, 高尔夫球运动已 经成为贵族运动的代名词。高尔夫球运动在绿色、有氧、 阳光的环境中进行, 在这项运动中, 享受大自然乐趣与体 育锻炼和游戏集于一体。威海大力发展高尔夫娱乐运动项 目, 诸多商务人士经常在闲㗇时间到威海来享受高尔夫运
动带来的享受, 又加上毗邻韩国, 很多韩国的旅人也经常 来威海进行高尔夫球运动, 形成了威海高尔夫休闲运动的 独特风景线。威海的高尔夫俱乐部 (会所)、练习场有十多 家, 比较有名的有: 锦湖韩亚高尔夫俱乐部, 高尔夫会所, 蓝天宾馆-高尔夫练习场, 金色海岸高尔夫俱乐部, 威海玛 斯特室内高尔夫, 友昌高尔夫练习场, 新星高尔夫练习场, 锦湖高尔夫俱乐部, 鹏达高尔夫, 培华高尔夫练习馆等。

\section{3 羽毛球}

羽毛球在威海也是相当受欢迎的休闲体育运动之一。 羽毛球场地限制小, 在空地、公园和广场等公共设施处就 可以进行, 有人称之为“空地羽毛球”, 运动器械简单, 只 需两只拍子一个球, 活动对象又以家庭成员、同事为多, 可以随时随地, 随心所欲地进行, 这是一种典型的喜闻乐 见的休闲体育活动。正是这种方便性和趣味性, 使得威海 羽毛球友众多。在威海, 羽毛球场地的建设也颇具规模。 威海市现有较大规模的羽毛球场馆 8 处。

\section{4 游泳}

游泳是一项老少皆宜的健身项目, 在我国的众多大中 城市里颇受欢迎, 有着广泛的群众基础。威海市近年来大 众游泳运动发展迅猛。这一方面是由于威海天然的海域游 泳资源为大众游泳运动提供了天然的物质条件, 另一方面, 近几年威海室内游泳场馆的建设有所增加, 也极大的解决 了季节对大众游泳运动的限制。另外, 威海市时常举行威 海市群众性游泳赛事, 也吸引了更多地人参与到了游泳运 动之中。

据调查, 威海游泳者游泳的单次时间长度主要集中在 1-1.5 个小时, 占到调查人数的 $42.9 \%$ 。这个时间范围既能 起到一定的体育锻炼作用, 同时也是休闲调整的合理时间。 威海市大众参加游泳健身活动的动机以强身健体、业余爱 好、消遣娱乐、缓解压力、调整情绪、交友为主要目的, 越来越多的人认识到游泳的休闲功能和健体功能, 使游泳 成为威海休闲体育最主要的运动形式。

\section{5 健身路径}

全民健身路径是极其普遍的休闲健身方式, 在全国都 有相当规模的建设, 并非威海独有。但是就健身路径的建 设程度及覆盖率来看, 威海健身路径的建设十分全面, 发 挥的作用也可想而知。健身路径有着方便、简单, 靠近居 民区和人员密集的公共区域的特点, 使用健身路径的大多 是老年人和少年儿童, 他们的主要目的就是休闲健身。据 统计, 威海市市区范围内健身设施普查, 健身器材数目达 
1688 件, 健身场地面积约 61620 平方米。威海市村委会全 民健身路径覆盖率达 $80.71 \%$, 威海市居委会全民健身设施 覆盖率达 $74.86 \%$ 。

除了上述介绍的主要体育休闲项目之外, 环海路骑行、 健步走等也成为威海近几年新兴的蓝色休闲体育项目, 受 到越来越多群众的追捧。

\section{2.“宜居之城”蓝色休闲体育的特色}

\section{1 传统性与现代性并存}

中国有着历史悠久、博大精深的传统文化, 凭借着这 种文化力量, 中华民族创造了无数壮美辉煌的篇章, 也无 不时刻体现着中华民族自强不息的精神。自古以来, 佛道 就在中国传统文化中产生了深远影响, 佛教的禅宗与道教 的修仙思想, 使相当多的中国人信奉 “生命在于静止” 的理 念, 注重通过“静”和“养”来达到健康长寿的目的。中国传 统体育大多正是围绕“养生”开展的。人们认为决定健康和 长寿的根本在于人体的内部和谐而不在于外部强壮。人在 “静”中求“动”, 将自己与自然交融, 与自然沟通, 将自身 体内的浊气排出, 并吸取大自然中的灵气 (真气), 以通达 五脏、调和六腑。因此, 中国传统体育在体育形态上强调 整体观和意念感受、动作简单而内涵深刻, 很少有强烈的 肌肉运动, 由此也形成了以修身养性为目标, 以个体、娱 乐、技艺、表演的健身和养生为主体的休闲体育方式。

而现代竞技体育项目源于西方。西方人信奉伏尔泰的 “生命在于运动”的理念, 以冒险勇进、外向探求的性格为 主, 其运动多为追求快速激烈, 具有一定的刺激性或冒险 性, 如拳击、击剑、摔跤、足球、篮球、斗牛、跳伞、赛 车等。进入近现代以来, 西方体育在追求速度和力量的目 标下又加入科技和人文的元素, 在动中求静, 在运动中获 得体质的增强。

就威海地区而言, 除了中国“宜居之城”的美誉, 还常 被人称为“安静的小城”。威海人的生活是带着些静烅和慵 懒的。正是这种独特的生活环境和生活习惯, 威海的蓝色 休闲体育形成了动静结合的“养生+娱乐”式的模式。威海的 蓝色休闲体育运动传承着中国传统体育“静”的特点, 缺少 激进和冒险行为, 更多地强调的是人与自然的统一, 身心 的融合与愉悦。随着现代竞技体育在全球的推广, 威海的 蓝色休闲体育更是吸收了时代的精华, 将中国传统体育文 化这种整体修炼和内在和谐之美, 与力和速相结合, 与现 代科学相结合, 形成新的独特风格。

\section{2 全民性与阶层性共显}

威海蓝色休闲体育具有全民参与的全民性特点。除了
健身路径的广泛覆盖使得几乎全部威海人的休闲健身从家 门口就能完成, 自 2001 年至今, 每年的 8 月上旬, 威海各 地都会举行各种形式的沙滩运动会。如: 2001 年 8 月 11 日, 首届国际时尚球类大赛在威海开幕, 人们在美丽的海 滩上嬉水、逐沙、玩球, 尽情领略了时尚休闲运动的韵味; 2010 年 8 月 8 日, 威海市全民健身日沙滩运动会在国际海 水浴场举行。

除了政府组织的全民健身，企业也组织的大型休闲娱 乐活动, 甚至网友们也会自发组织的沙滩趣味运动会。如 那香海海水浴场组织的沙滩亲子运动会、威海的白领组织 进行的“第二届威海网友节”沙滩趣味运动会等。这些运动 会的项目丰富多彩, 具体的项目包括游泳、拔河、沙滩足 球、沙滩排球、雕沙堡等, 这些运动对技术要求较低, 大 家很容易就能参与其中, 各得其乐, 体现出了全民性的特 点。

同样, 威海有些体育休闲项目则有一定的阶层性, 或 专业性的倾向。比如帆船, 潜水, 高尔夫等, 是需要有一 定的专业技术支撑的, 同样花费也较高, 只有社会阶层较 高的人才能有时间和资金的保障经常参加。因此, 威海的 蓝色休闲体育又呈现出了全民性和阶层性共显的特点。

\section{3 季节性与旅游性突出}

打造“蓝色休闲之都世界宜居城市”的城市品牌是威海 城市发展的主要内容之一。夏季是威海休闲体育的热门时 期, 海水、阳光、沙滩是威海旅游的三大主要元素, 吸引 着诸多体育爱好者, 而威海绝大部分的特色休闲体育项目 需要依赖较好的天气条件。尽管威海临近海洋, 带有海洋 气候冬暖夏凉, 气候温润的特点, 但威海的气候类型仍是 温带大陆性气候。由于气候的原因, 威海在冬季风大雪多, 气温较低, 对休闲体育的进行有着较大影响。以全民健身 路径为例, 在调查中, 冬季进行健身路径运动的人数约是 夏季的 $1 / 4$, 使用健身路径的次数也仅为夏季的 $1 / 3$, 这也 体现出威海蓝色休闲体育的季节性特点。当然, 随着诸多 室内场馆建设的增加和休闲体育形式的多样化, 使得这种 季节性特点有减弱的趋势。

休闲体育产业化发展趋势使得体育旅游成为休闲体育 的热点。此现象引起了许多学者的关注, 陈涛认为“体育旅 游是以休闲度假、观光探险、康健娱乐为目的, 在一定自然 环境中, 从事以体育项目为内容的旅游活动。”威海作为一个 著名的旅游城市, 尤其是夏季, 外来人口剧增, 来自全国 各地, 甚至全球的友人 (尤以俄罗斯人和韩国人居多) 来 威海度假, 并参加诸如高尔夫、帆船、游泳等运动。因此, 威海便形成了这种独具特色的蓝色休闲体育与休闲旅游相 结合的形势。 
威海地区的蓝色休闲体育现已有着一定程度的发展, 也形成了自己与众不同的特点。威海市体育局为了进一步 推动全民健身, 让市民更多地参与到休闲体育中, 制定了 “211 工程”建设计划, 即“两点一线一面”工程建设。两点是 威海市全民健身中心和乐天休闲体育公园, 一线是指幸福 海岸健身长廊, 一面则指普及建设农村体育健身工程。其 中包括的室内健身场、儿童乐园、网球场、篮球场、环海 旅游健身圈等。这一举措进一步推进了威海蓝色休闲体育 的发展。当然, 威海休闲体育的建设仍有很大的发展空间。 因此, 如何发挥威海独特的休闲体育特色, 形成威海独特 的蓝色休闲体育文化, 并做好群众性休闲体育文化活动的 推广普及工作, 同时加强休闲体育基础设施的建设, 引导 广大民众积极开展健康有益的休闲体育文化活动, 创造良
好的休闲体育文化环境, 引导每一个人热爱运动, 在运动 中获得健康、享受快乐, 仍是一个具有思考意义的课题。

\section{参考文献 (References)}

[1] Lu Yuan Zhen. Sports Sociology. Higher Education Press, 2002.

[2] Chen Xin Sheng, Chu Ji Jun. Current Situation and Countermeasures of Public Service of Leisure Sports in City Communities. Journal of Xi'an Institute of Physical Education, 2011.

[3] Chen Tao. Preliminary Research on Sports Tourism. Journal of Guangzhou Physical Education Institute, 2000. 